\title{
SISTEM INFORMASI PENJUALAN JILBAB PADA TOKO KARUNIA BUKITTINGGI DENGAN BAHASA PEMROGRAMAN PHP DAN MYSQL
}

\author{
Yeyi Gusla Nengsih \\ Perekam Medis dan Informasi Kesehatan, Universitas Imelda Medan, Sumatera Utara \\ yeyigusla22@gmail.com
}

\begin{abstract}
ABSTRAK
Website Toko Karunia Bukittinggi dirancang untuk sebuah sistem pemesanan on-line. Tujuan dari perancangan sistem ini adalah untuk memberikan pelayanan pemesanan secara on-line dan informasi yang lengkap tentang produk yang ditawarkan perusahaan kepada masyarakat luas. Penelitian ini dilakukan dengan beberapa metode yaitu Metode Pegumpulan Data, diantaranya Penelitian Lapangan, Penelitian Perpustakaan dan Penelitian Laboratorium. Metode Analisa dan Desain untuk menganalisa dan mendesain data-data yang tersedia dengan menggunakan UML (Unified Modelling Language) dengan jenis-jenis diagramnya adalah Use Case Diagram, Class Diagram, Sequency Diagram, Activity Diagram dan didukung dengan penggunaan alat bantu software dan hardware yang berguna untuk pengolahan data yang ada. Dari penelitian tersebut dihasilkanlah sebuah Sistem Informasi Pengolahan data yang interaktif dan dinamis serta lengkap mengenai pemasaran produk lewat transaksi secara on-line.
\end{abstract}

Kata kunci : penjualan, sistem informasi, jilbab, website

\begin{abstract}
Website of Toko Karunia Bukittinggi is designed for an on-line booking system. The purpose of the design of this system is to provide reservation services on-line and complete information about the products offered by the company to the public. This research was carried out by several methods: Method data Collection, including field research, Research Library and Research Laboratory. Methods of Analysis and Design for analyzing and designing data available using UML (Unified Modeling Language) with the kinds of diagrams is the Use Case Diagram, Class Diagram, sequency Diagram, Activity Diagram and supported by the use of software tools and hardware useful for the processing of existing data. From these studies be produced a Data Processing Information Systems are interactive and dynamic as well as complete the marketing of products through on-line transactions.
\end{abstract}

Keywords: information systems, sales hijab, website

\section{PENDAHULUAN}

Dunia teknologi informasi dan komputer pada saat ini berkembang pesat, mengakibatkan banyak perubahan yang terjadi dalam kehidupan manusia. Hal ini dapat kita lihat dengan semakin mudah dan cepatnya manusia dalam memperoleh informasi yang dibutuhkan. Dengan adanya perkembangan teknologi, setiap pekerjaan akan dapat direalisasikan secara lebih efisien dan efektif. Apa lagi saat ini dengan mudah menggunakan browser untuk mendapatkan informasi yang di perlukan dalam proses transaksi pembelian. Hal ini juga dapat mempermudah pihak penjualan secara 
online dalam menyampaikan informasi penjualan mereka [4].

Proses penjualan jilbab pada Toko Karunia masih memiliki keterbatasan atau kekurangan. Penjualan yang dilakukan hanya sebatas pada Toko yang mereka miliki, dampak dari penjualan seperti ini adalah produk yang dijual terbatas pada pelanggan tertentu saja. Pelanggan yang ingin membeli suatu produk harus datang ke Toko Penjualan jilbab untuk melakukan transaksi pembelian. Hal ini menimbulkan banyak kendala terutama bagi para pelanggan yang tidak mempunyai banyak waktu luang.

\section{Pengertian CRM}

Albertus Januaris Kundre dari STMIK AMIKOM Yogyakarta pada tahun 2013 juga melakukan penelitian dengan judul "Penerapan Customer Relationship Management Dengan Dukungan Teknologi Informasi Pada PO.Chelsy", menyatakan bahwa CRM merupakan strategi dan usaha untuk menjalin hubungan dengan pelanggan dan memberikan pelayanan yang memuaskan bagi pelanggan [5]. CRM mendukung suatu perusahaan untuk menyediakan pelayanan kepada pelanggan secara real-time dengan menjalin hubungan dengan tiap pelanggan yang berharga melalui penggunaan informasi tentang pelanggan [3]. Berdasarkan apa yang diketahui dari pelanggan, perusahaan dapat membuat variasi penawaran, pelayanan, program, pesan, dan media [6].

\section{Konsep Dasar Sistem Informasi}

Manajer yang tidak memiliki kemampuan menggunakan komputer mungkin akan menjadi penghambat bagi organisasi, atau lebih buruk lagi tak bermanfaat sebagai pengambilan keputusan. Kesimpulan tersebut mencerminkan kenyataan bahwa untuk beberapa dekade, fokus pada penggunaan komputer lebih tertuju kepada mesin ketimbang kepada dimensi yang jauh lebih penting, yaitu penerapannya. Meskipun fakta menunjukan bahwa komputer tidak lebih dari sekedar sebuah alat pengolahan data, banyak manajer memandangnya sebagai elemen sentral yang penting dalam suatu sistem informasi [1]. Sikap ini cenderung menyanjung dan merancukan peran komputer yang sesungguhnya, yaitu menyajikan informasi untuk pengambilan keputusan dan untuk perencanaan serta pengendalian operasi [1]

\section{Pengertian Sistem}

Sistem adalah sekelompok unsur yang erat hubungannya satu sama lain, yang berfungsi bersama-sama untuk mencapai tujuan tertentu. Norman L.Enger menyatakan bahwa suatu sistem dapat terdiri atas kegiatan-kegiatan yang berhubungan guna mencapai tujuan-tujuan perusahaan. Sedangkan Prof. Dr. Mr. S. Prajudi Atmosudirjo menyatakan bahwa suatu sistem terdiri atas objek-objek atau komponen-komponen yang berkaitan dan berhubungan satu sama lainnya sehingga unsur-unsur tersebut merupakan suatu kesatuan pemrosesan atau pengolahan [1].

\section{Pengertian Informasi}

Informasi adalah data yang telah di klasifikasikan atau di interprestasi untuk digunakan dalam proses pengambilan keputusan [2]

\section{Pengertian Sistem Informasi}

Sistem informasi dapat didefenisikan sebagai suatu sistem didalam suatu organisasi yang mempertemukan kebutuhan pengolahan transaksi harian, mendukung fungsi organisasi yang bersifat manajerial dengan kegiatan strategi dari suatu organisasi untuk dapat menyediakan laporan-laporan yang diperlukan pihak luar tertentu [2] 


\section{METODE PENELITIAN}

Dari kasus yang ada pada Toko Karunia Bukittinggi penulis memilih target untuk menyelesaikan masalah menggunakan metode penelitian yang dilakukan secara sistematik yaitu sebagai pedoman dalam pelaksanaan penelitian ini, agar hasil yang dicapai tidak menyimpang dari tujuan yang telah ditentukan sebelumnya. Adapun penelitian ini yakni penjualan jilbab berbasis web yang didukung dengan bahasa pemrograman web dan mysql. Pengumpulan data dilakukan secara observasi yaitu dengan datang langsung kelapangan sehingga menggambarkan realitas masalah yang sebenarnya.

Adapun tahapan metode penelitian ini sehingga tidak terjadi kerancuan dan solusi yang dicapai maksimal adalah sebagai berikut :

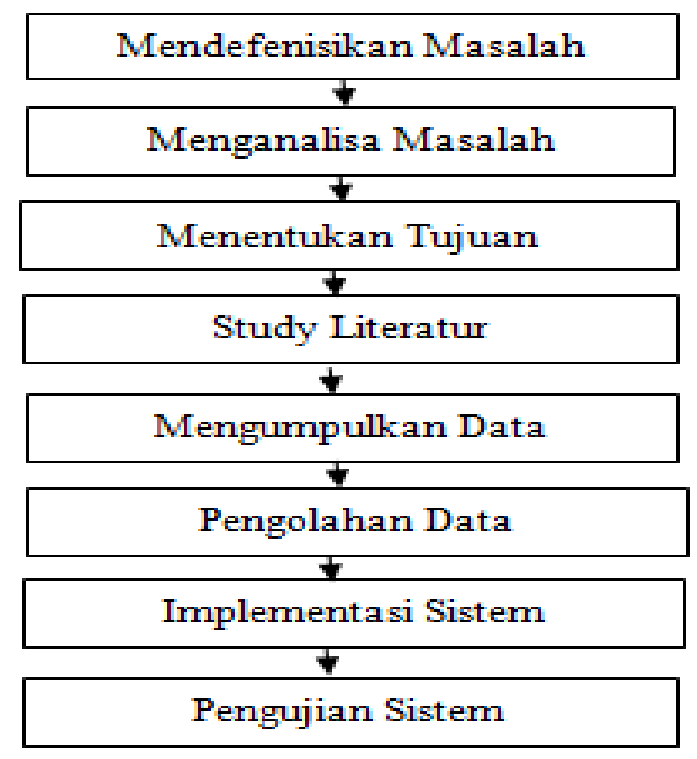

Gambar 1. Kerangka kerja Penelitian

1. Mengidentifikasi Masalah

Pada tahap ini dilakukan peninjauan dan mengamati sistem yang akan diteliti serta melakukan eksplorasi lebih dalam.
2. Menganalisa Masalah

Setelah permasalahan nya ditemukan, selanjutnya dilakukan lagi analisa terhadap masalah

3. Menentukan Tujuan

Dari permasalahan yang telah dianalisa, langkah berikutnya ditentukan lagi tujuan yang ingin dicapai dalam penelitian ini.

4. Studi Literatur

Dalam penelitian ini, penulisan menggunakan referensi dari berbagai kaidah, buku-buku, jurnal, teori-teori dll.

5. Mengumpulkan Data

Dalam tahap ini, proses pengumpulan data secara observasi lapangan yaitu datang langsung ke Toko Karunia Bukittinggi dilakukan selama 2hari berturut-turut yang dipilih tanggal $20-21$ juni 2018.

6. Implementasi Sistem

Sesuai dengan pengolahan data maka tahap implementasi pada kasus ini didukung dengan software PHP dan database MySQL.

Software yang dibutuhkan :

a. Microsoft windows 7 ultimate

b. Microsoft office 2007

c. Aplikasi mozila firefox

d. Software PHP

e. XAMPP

Hardware yang dibutuhkan :

a. Laptop TOSHIBA-PC 32bit

b. $2.00 \mathrm{~GB}$ RAM

c. Hardisk 200GB

d. Monitor, Mouse dan Printer

7. Pengujian Sistem

Pada tahap ini adalah tahap akhir dalam penelitian, pada tahap ini dilakukan penilaian apakah perangkat lunak yang dikembangkan telah sesuai dengan tujuan yang diharapkan atau belum. 


\section{ANALISA DAN PEMBAHASAN Analisa Sistem}

Analisa sistem adalah penguraian dari suatu sistem informasi yang utuh kedalam bagianbagian komponennya dengan maksud untuk mengidentifikasi dan mengevaluasi permasalahan, kesempatan, dan hambatanhambatan yang mungkin terjadi serta kebutuhan yang diharapkan sehingga dapat diusulkan perbaikan [2].

\section{Aliran Sistem Kerja Lama}

Setelah melakukan penelitian langsung ke lapangan terhadap sistem informasi yang sedang berjalan pada Toko Karunia Bukittinggi, peneliti mengetahui bahwa pada proses transaksi penjualan dan pemesanan jilbab dilakukan secara langsung tanpa melalui media atau aplikasi apapun. Apabila konsumen menginginkan model atau warna lain dari jenis jilbab tersebut, maka konsumen harus datang dan menanyakan langsung ke Toko Karunia Bukittinggi. Setelah konsumen memperoleh informasi tentang produk yang diinginkan, barulah konsumen membeli produk yang dimaksud. Dan apabila produk yang diinginkan tidak ada, konsumen harus menunggu produk tersebut untuk di produksi lagi. Jadi dapat diambil kesimpulan bahwa sistem yang sedang berjalan pada Toko Karunia Bukittinggi masih dilakukan secara manual dan berikut adalah alur pada Toko Karunia Bukittinggi :

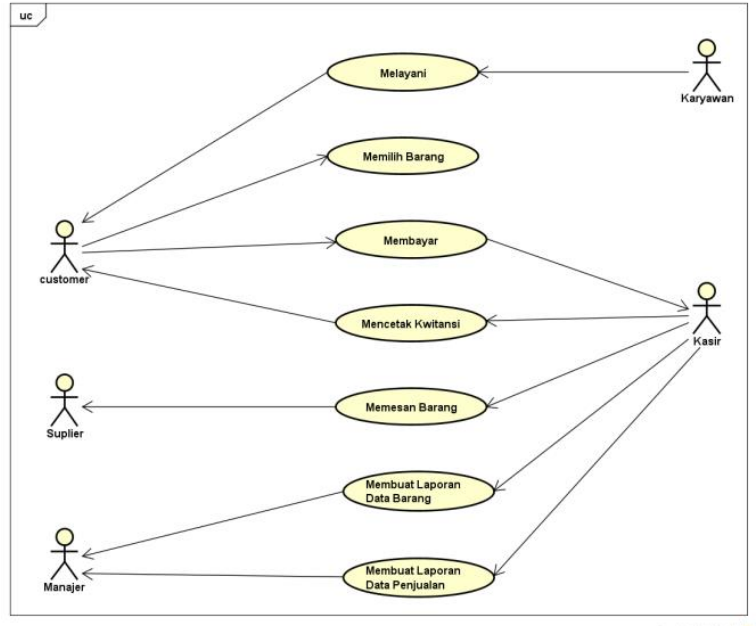

Gambar 2. Sistem kerja Lama Toko Karunia Bukittinggi

\section{Analisa Sistem Kerja Baru Use Case Diagram}

Dalam Use Case Diagram tersebut menggambarkan dimana aktor harus memiliki aplikasi penjualan. Admin juga harus login agar bisa melakukan pengolahan sistem. Admin memiliki fasilitas lengkap dalam pengolahan seperti lihat, tambah, edit, hapus dan memberikan solusi. Member hanya memiliki fasilitas seperti menggunakan sistem dalam hal pembelian produk. Sedangkan non-member hanya bisa melihat halaman web saja, dan terlebih dahulu harus melakukan transaksi pendaftaran member untuk bisa login sebagai member.

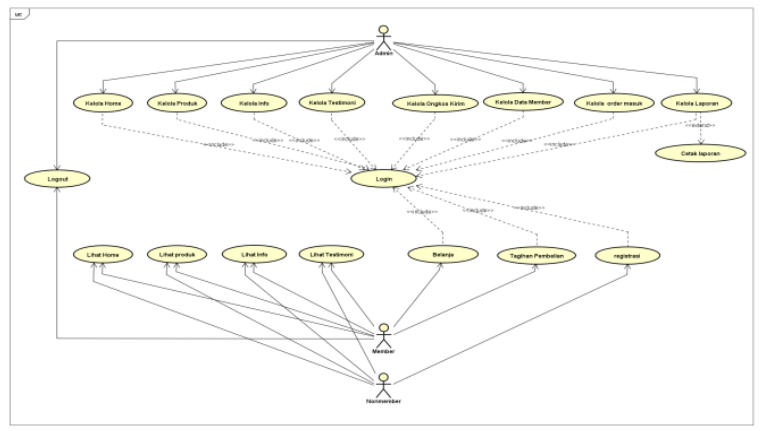

Gambar 3. Use Case Diagram 


\section{Class Diagram}

Class Diagram pada sistem penjualan ini, User sekaligus member dalam sistem ini adalah seorang pengguna yang dapat melakukan registrasi untuk pembelian produk maka data user tersebut disimpan pada tabel member dan data pada tabel member digunakan untuk login pada sistem.

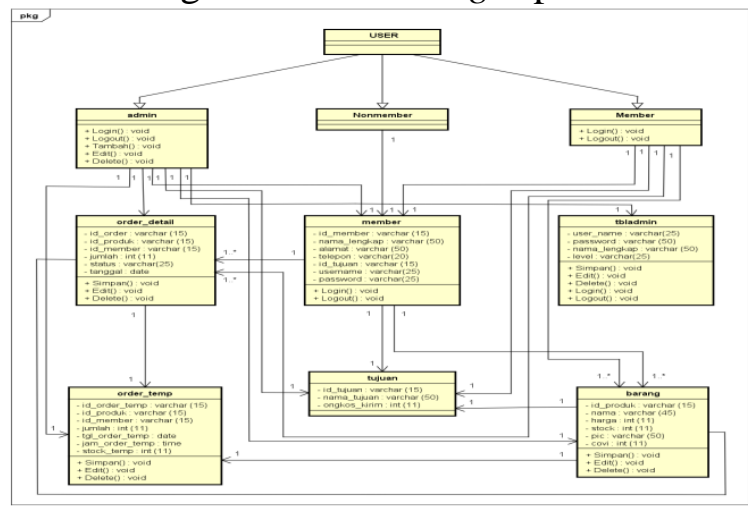

Gambar 4. Class Diagram

\section{Sequence Diagram}

Sequence Diagram Admin Login Sistem

Diagram ini menjelaskan urutan langkahlangkah yang dilakukan seorang admin untuk login sistem.

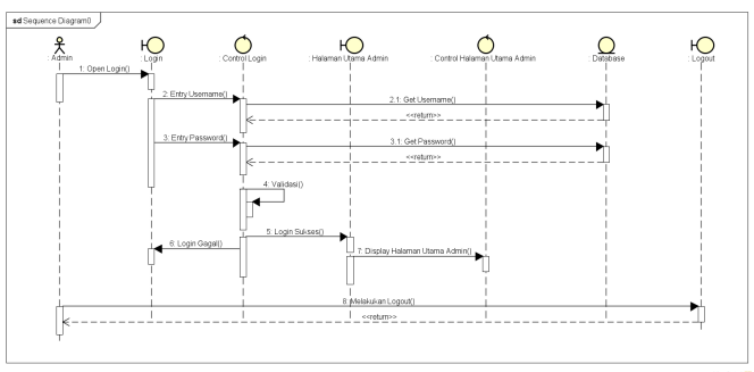

Gambar 5. Sequence Diagram Admin login system

\section{Sequence Diagram Managenent Member} Sequency diagram management member menggambarkan proses admin untuk melakukan pilihan lihat, edit, hapus member.

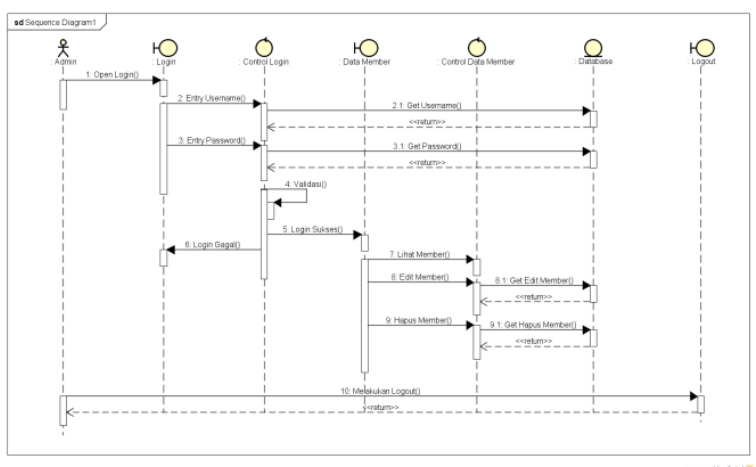

Gambar 6. Sequence Diagram Management Member

\section{Sequence Diagram Order Barang}

Sequency diagram order barang menggambarkan proses user (member) untuk bisa melakukan pilihan lihat produk, tambah produk, ubah produk, hapus produk, setelah selesai user (member) bisa mengorder produk yang dibelinya.

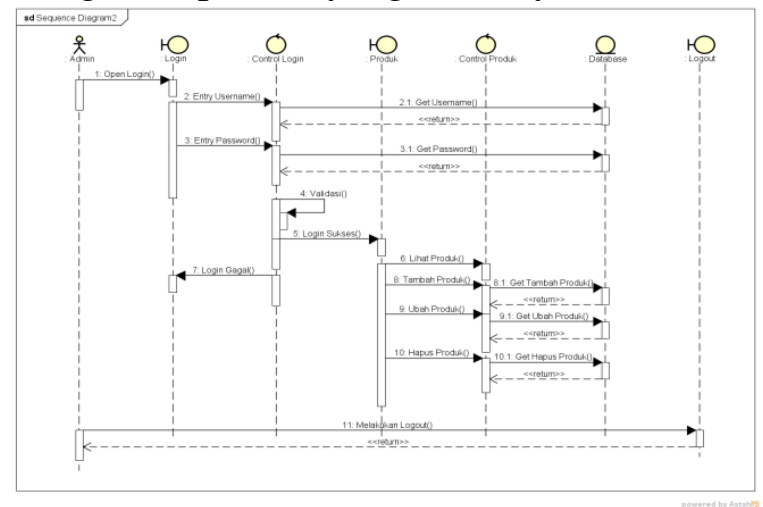

Gambar 7. Sequence Diagram Order Barang

\section{Activity Diagram}

\section{Activity Diagram Admin}

Activity diagram admin menggambarkan segala aktivitas yang bisa dilakukan oleh admin terhadap sistem yang dimulai dengan melakukan login terlebih dahulu, setelah itu barulah bisa memilih menu-menu yang tersedia untuk mengelola aktifitas dalam sistem 


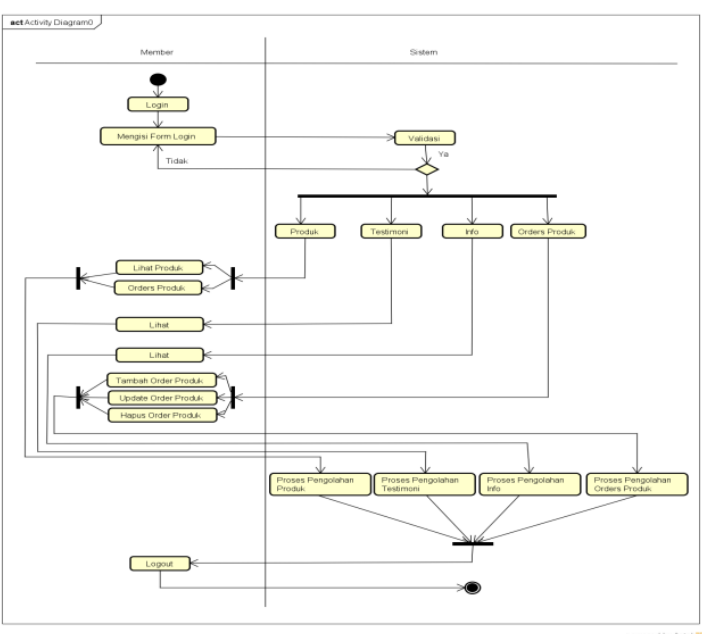

Gambar 8. Activity Diagram Admin

\section{Activity Diagram Nonmember}

Activity diagram nonmember menggambarkan segala aktivitas yang bisa dilakukan oleh nonmember adalah melihat produk-produk yang ada. Dan jika nonmember ingin belanja, maka nonmember harus registrasi dulu untuk bisa menjadi member.

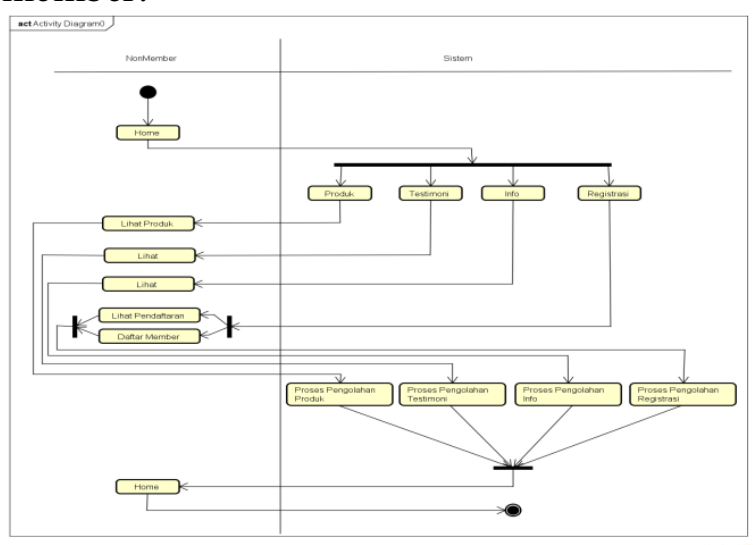

Gambar 9. Activity Diagram Nonmember

\section{Pengujian Sistem}

Pengujian sistem mengambarkan bagaimana sebuah sistem berjalan. Tahapan pengujian ini berisikan hasil eksekusi program dan penjelasan program yang dibuat yang telah dirancang.

\section{Halaman Menu Utama}

Desain tampilan menu utama tersedia menu home, login admin, login member.

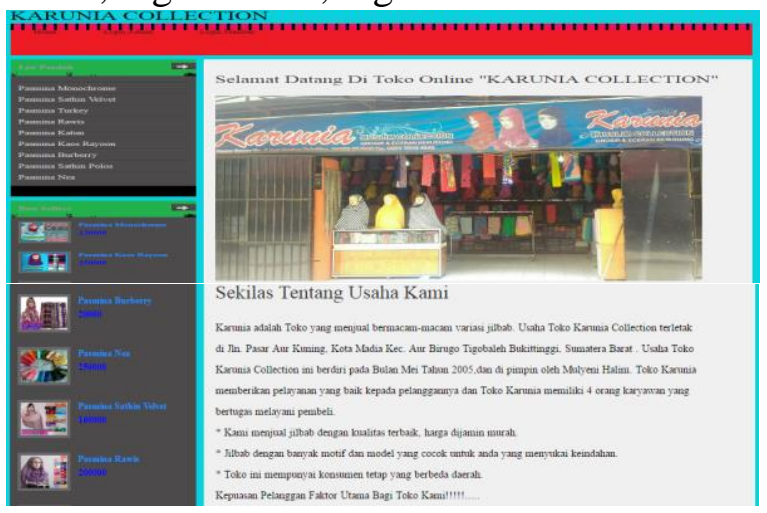

Gambar 10. Menu Utama

\section{Halaman Login Admin}

Menu login admin digunakan untuk dapat masuk ke dalam sistem web server dengan memasukkan username dan password yang telah didaftarkan sebelumnya.

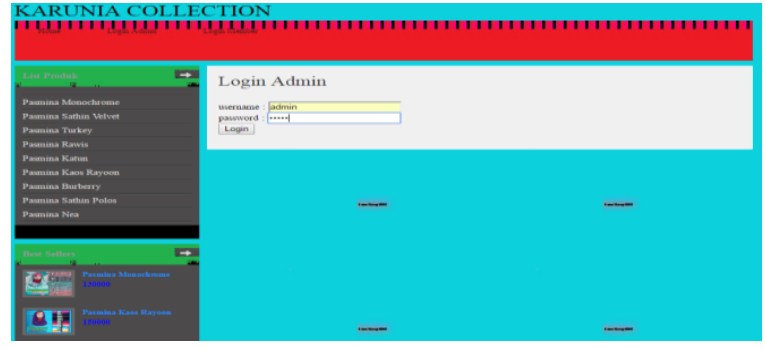

Gambar 11. Login Admin

\section{Halaman Admin}

Halaman ini hanya dapat di akses oleh admin. Dihalaman inilah admin bekerja dengan memilih menu yang ada.

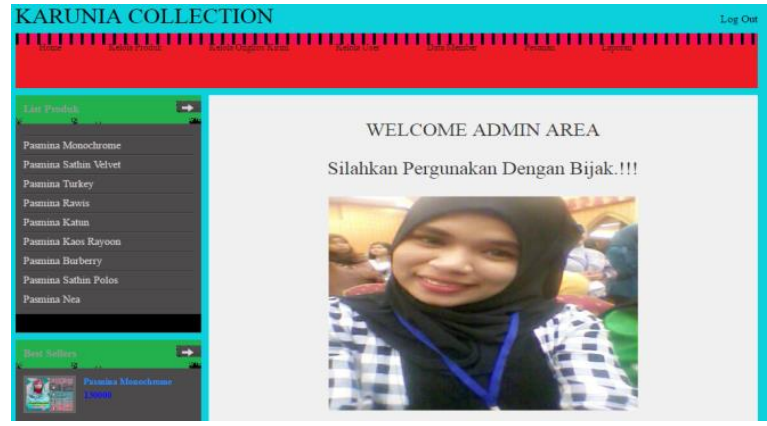

Gambar 12. Halaman Admin 


\section{Tampilan Form Daftar Member}

Pada layout daftar member ini, nonmember dapat mendaftar terlebih dahulu dan login sebagai member sebelum melakukan pembelian produk

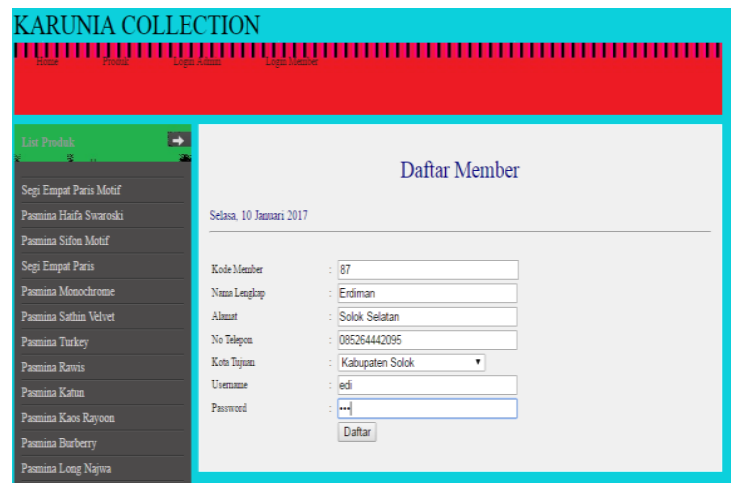

Gambar 13. Daftar Member

\section{Tampilan Halaman Produk}

Pada menu ini, member dapat melihat berbagai jenis produk yang tersedia.

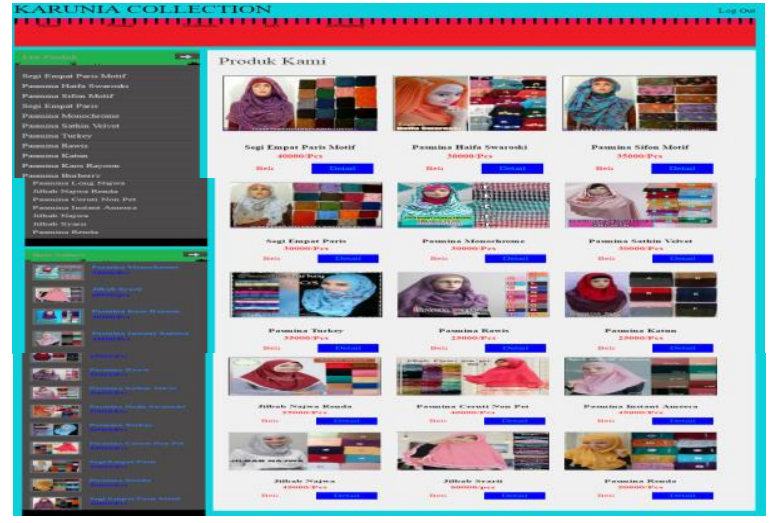

Gambar 14. Produk

\section{Tampilan Halaman Keranjang Belanja}

Pada menu ini, member dapat melakukan transaksi pembelian produk pada keranjang yang tersedia

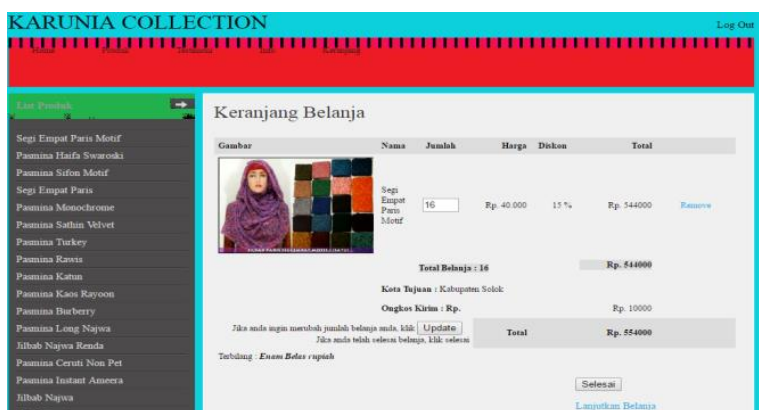

Gambar 15. Keranjang Belanja

\section{Tampilan Halaman Tagihan Yang Harus Dilunasi}

Pada menu ini, member harus melakukan transaksi pembayaran setelah memesan produk.

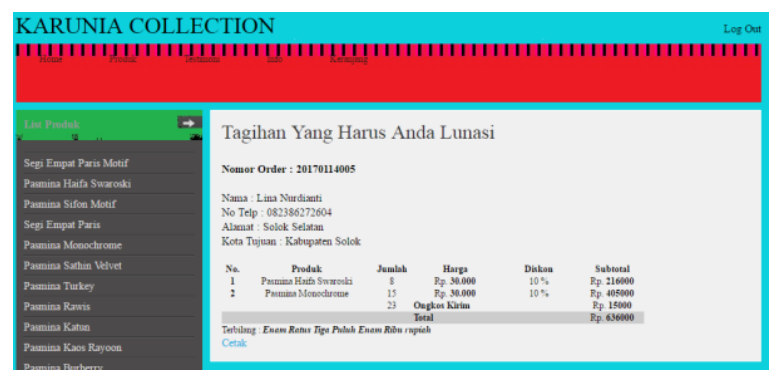

Gambar 16. Tagihan

\section{Tampilan Halaman Konfirmasi Pembayaran}

Pada menu ini, member harus melakukan konfirmasi pembayaran setelah memesan produk

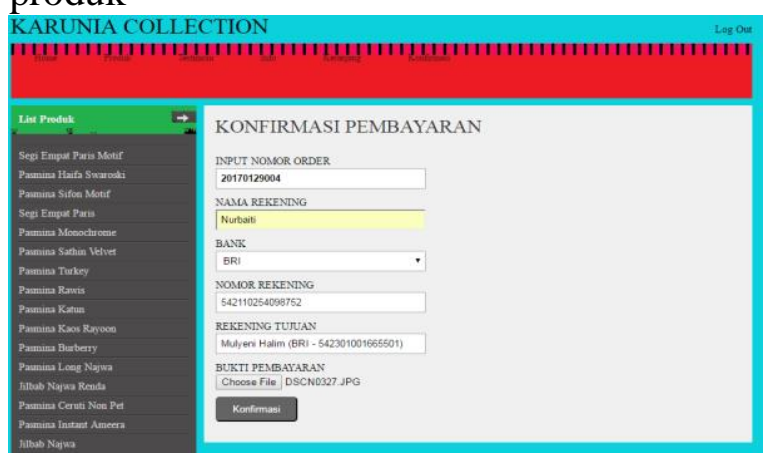

Gambar 17. Konfirmasi Pembayaran 


\section{Tampilan Halaman Cetak Bukti Pemesanan}

Pada menu ini, member dapat mencetak bukti pemesanan produk yang telah dipesan

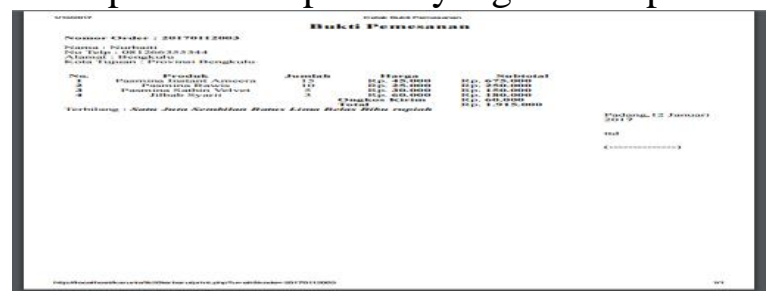

Gambar 18. Cetak Bukti

\section{KESIMPULAN}

Adapun kesimpulan yang dapat ditarik dari pembahasan skripsi ini adalah :

1. Dengan adanya sistem komputerisasi ini, maka karyawan pada Toko Karunia Bukittinggi lebih mudah dalam menyajikan informasi tentang penjualan dan penyediaan barang.

2. Pengolahan data penjualan dan penyediaan barang di Toko Karunia Bukittinggi tidak lagi menggunakan penulisan langsung pada kertas sehingga tidak menghambat proses transaksi.

3. Dengan penggunaan dan pemanfaatan sistem informasi berbasis komputer secara optimal maka akan menghasilkan suatu informasi yang tepat, cepat dan akurat.

4. Dengan adanya komputerisasi yang dilengkapi dengan Bahasa Pemrograman PHP akan membantu dalam pengambilan keputusan yang cepat.

\section{DAFTAR PUSTAKA}

[1] Ade, H. (2016) 'Pemodelan sistem informasi monitoring penjualan dan stock barang (study kasus distro zhezha pontianak)', Jurnal Khatulistiwa Informatika, pp 503-511

[2] Amri, S. R., Retnadi, E., and Supriatna, A. D.(2013) 'Perancangan sistem informasi berbasis website subsistem guru di sekolah pesantrean persatuan islam 99 rancabango' Jurnal Algoritma, pp 327-337.

[3] Dyantina, O., Afrina. M. and Ibrahim, A. (2012) 'Penerapan customer relationship management (CRM) berbasis web (study kasus pada sistem informasi di toko yen-yen', Jurnal Sistem Informasi (JSI), pp. 516-529. http:// ejournal.unsri.ac.id/index.php/jsi/index.

[4] Februariyanti, H. and Zuliarso, E. (2012) 'Rancang bangun sistem perpustakaan untuk jurnal eletronik', 2012 Jurnal Teknologi Informasi DINAMIK, pp. 124-132.

[5] Kundre, A. J., Wisnubadhra, I. and Kundre, A. J. (2013) 'Penerapan customer relationship management dengan dukungan teknologi informasi pada po. chelsy', Seminar Nasional Teknologi Informasi dan Multimedia 2013, pp. 201-209.

[6] Kalalo, E. R. (2013) 'Customer relationship management dan kualitas pelayanan pengaruhnya terhadap loyalitas konsumen pt. matahari dept. store manado', Jurnal EMB A, pp. 15531561. 